\title{
PERBEDAAN KARAKTERISTIK PETANI DAN USAHATANI MANGGA DI KECAMATAN PANYINGKIRAN, KABUPATEN MAJALENGKA DAN KECAMATAN JAPARA, KABUPATEN KUNINGAN
}

\section{DIFFERENCES BETWEEN CHARACTERISTICS OF FARMERS AND MANGO FARMING IN PANYINGKIRAN DISTRICT, MAJALENGKA REGENCY AND JAPARA DISTRICT, KUNINGAN REGENCY}

\author{
Elly Rasmikayati ${ }^{1}$, Akbar Adiputra Irawan ${ }^{1}$, Bobby Rachmat Saefudin ${ }^{* 2}$, \\ Nur Syamsiyah $^{1}$, Endah Djuwendah ${ }^{1}$ \\ ${ }^{1}$ Fakultas Pertanian, Universitas Padjajaran \\ ${ }^{2}$ Fakultas Pertanian, Ma'soem University \\ *E-mail: bobbyrachmat@masoemuniversity.ac.id \\ (Diterima 29-06-2021; Disetujui 22-07-2021)
}

\begin{abstract}
ABSTRAK
Provinsi Jawa Barat merupakan daerah yang produktif dan memiliki potensi agribisnis mangga yang dapat dikembangkan. Kabupaten Majalengka dan Kabupaten Kuningan merupakan daerah sentra produksi mangga yang memiliki perbedaan dalam jumlah produksi mangga yang dihasilkan. Tujuan penelitian ini adalah untuk menganalisis perbedaan karakteristik petani dan usahatani mangga di Kecamatan Panyingkiran dan Kecamatan Japara. Penelitian ini merupakan penelitian kuantitatif dengan menggunakan data sekunder. Metode penelitian yang digunakan adalah metode survey. Pengambilan sampel sebanyak 130 orang petani mangga di Kecamatan Panyingkiran dan 130 orang petani mangga di Kecamatan Japara. Penelitian ini menggunakan analisis deskriptif, Independent sample T-test dan Mann Whitney U-test. Hasil penelitian ini menunjukkan bahwa karakteristik petani dan usahatani mangga antara Kecamatan Panyingkiran dan Kecamatan Japara memiliki perbedaan yang signifikan dalam aspek usia petani, jenis kelamin petani, tingkat pendidikan petani, pekerjaan utama ataupun pekerjaan sampingan petani, pengalaman usahatani petani mangga, pendapatan petani dari bertani maupun selain bertani mangga dan penguasaan lahan petani mangga yang terdiri atas total luas lahan dan jumlah pohon mangga.
\end{abstract}

Kata kunci: Perbedaan, Karakteristik, Petani, Usahatani, Mangga

\section{ABSTRACT}

West Java Province is a productive area and has the potential for developing mango agribusiness. Majalengka and Kuningan districts are mango production centers which differ in the amount of mango production produced. The objectives of this study were: to analyzing the differences about characteristics of farmers and mango farming in Panyingkiran and Japara Districts. This research is a quantitative study using secondary data. The research method used is the method of survey results. Sampling was 130 mango farmers in Panyingkiran District and 130 mango farmers in Japara District. This research uses descriptive analysis, Independent sample T-test and Mann Whitney U-test. The results of this study indicate the characteristics of farmers and mango farming between Panyingkiran and Japara Districts have significant differences in term of the age of the farmer, the gender of the farmer, the education level of the farmer, the main job or the farmer's side job, the experience of farming mango farmers, the farmer's income from farming or other than farming. mango and mango farmer land tenure consisting of the total area of land and the number of mango trees.

Keywords: Difference, Characteristics, Farmer, Farming, Mango 
PERBEDAAN KARAKTERISTIK PETANI DAN USAHATANI MANGGA DI KECAMATAN

PANYINGKIRAN, KABUPATEN MAJALENGKA DAN KECAMATAN JAPARA, KABUPATEN KUNINGAN

Elly Rasmikayati, Akbar Adiputra Irawan, Bobby Rachmat Saefudin, Nur Syamsiyah, Endah Djuwendah

\section{PENDAHULUAN}

Indonesia memiliki beberapa provinsi unggulan yang menjadi sentra produksi mangga nasional. Menurut Badan Pusat Statistik (2019), terdapat 3 daerah sentra produksi mangga unggulan di Indonesia diantaranya adalah Jawa Timur, Jawa Tengah dan Jawa Barat.

Tabel 1. Jumlah Produksi dan Produktivitas Mangga Provinsi Unggulan di Indonesia

\begin{tabular}{lcccc}
\hline \multirow{2}{*}{ Provinsi } & \multicolumn{2}{c}{ Total Produksi (Ton) } & \multicolumn{2}{c}{$\begin{array}{c}\text { Produktivitas } \\
\text { (Ton/Hektar) }\end{array}$} \\
\cline { 2 - 5 } & 2018 & 2019 & 2018 & 2019 \\
\hline Jawa & 1.059 .325 & 1.148 .121 & 12,71 & 10,4 \\
\hline Timur & 443.487 & 485.041 & 12,06 & 8,9 \\
\hline Tengah & 4406 & 14,31 & 11,1 \\
\hline Jawa & 404.543 & 418.522 & &
\end{tabular}

Sumber : Badan Pusat Statistik, 2018 (diolah)

Berdasarkan Tabel 1, Provinsi Jawa Barat berada di urutan ketiga sebagai sentra produksi buah mangga di Indonesia. Walaupun berada di urutan ketiga, pada tahun 2018-2019 Jawa Barat memiliki total produktivitas terbesar diantara daerah produksi mangga unggulan lainnya. Hal ini berarti Jawa Barat merupakan daerah yang produktif dan memiliki potensi agribisnis mangga yang dapat dikembangkan.

Menurut Mukti dkk (2019), daerah sentra produksi mangga di Provinsi Jawa Barat tersebar di Kabupaten Indramayu, Kabupaten Sumedang, Kabupaten
Cirebon, Kabupaten Majalengka, dan Kabupaten Kuningan.

Tabel 2. Data Produksi Buah Mangga di Wilayah Sentra Mangga Jawa Barat

\begin{tabular}{lc}
\hline \multicolumn{1}{c}{ Kabupaten } & $\begin{array}{c}\text { Kontribusi Produksi Mangga } \\
\text { Jawa Barat 2015-2019 }\end{array}$ \\
\hline Indramayu & 23,63 \\
Majalengka & 15,22 \\
Sumedang & 13,05 \\
Cirebon & 12,21 \\
Kuningan & 8,14 \\
\hline Sumber : Badan Pusat Statistik, 2015-2019 (diolah)
\end{tabular}

Berdasarkan Tabel 2, menunjukkan bahwa Kabupaten Indramayu merupakan peringkat pertama terhadap kontribusi total produksi mangga Jawa Barat tahun 2015-2019. Menurut Kementerian Pertanian (2018), rata-rata luas lahan panen mangga yang dimiliki daerah tersebut pada tahun 2018 sebesar 4.084 Ha sehingga membuat daerah tersebut layak berada di urutan pertama sebagai penghasil mangga terbesar di Jawa Barat. Daerah selanjutnya Kabupaten Majalengka yang merupakan peringkat kedua dengan rata-rata luas lahan panen mangga yang dimiliki pada tahun 2018 sebesar 3.008,64 Ha, sedangkan Kabupaten Kuningan berada pada posisi kelima atau posisi terakhir dengan luas lahan panen mangga yang dimiliki di tahun 2.018 sebesar $3147,3 \mathrm{Ha}$.

Melihat hasil data total produksi yang dimiliki Kabupaten Majalengka dan Kabupaten Kuningan terhadap rentang 
tahun tersebut, kedua daerah itu memiliki perbedaan total produksi yang jauh sekali atau sekitar 7,06 persen. Kabupaten Kuningan memiliki total produksi yang jauh lebih rendah dibandingkan Kabupaten Majalengka, padahal luas lahan panen yang dimiliki kedua daerah tersebut tidak berbeda jauh bahkan Kabupaten Kuningan memiliki luas lahan panen yang lebih besar dibandingkan Kabupaten Majalengka.

Suratiyah (2006) menjelaskan bahwa kegiatan produksi menunjukkan bagaimana petani mengelola sumberdaya yang dimiliki secara efisien terhadap usaha pertanian yang dilakukan, dan bagaimana petani mengambil sebuah keputusan. Selain itu, menurut Manyamsari dkk. (2014), pengambilan keputusan atau tindakan petani tersebut berasal dari karakteristik petani itu sendiri. Karakteristik petani akan mencerminkan perilaku yang menggambarkan motivasi, karakteristik kepribadian, dan keahlian atau pengetahuan petani melakukan kegiatan produksi mangga.

Melihat perbedaan produksi yang terjadi di kedua daerah tersebut, terdapat pemikiran apakah ada perbedaan yang terjadi terhadap karakteristik petani dan usahatani mangga diantara petani di
Kecamatan Panyingkiran, Kabupaten Majalengka dan Kecamatan Japara, Kabupaten Kuningan yang merupakan kedua daerah sentra produksi mangga di Jawa Barat. Berdasarkan uraian yang telah dijelaskan, tujuan penelitian ini adalah untuk mengetahui karakteristik petani dan usahatani mangga di Kecamatan Panyingkiran dan Kecamatan Japara.

\section{METODE PENELITIAN}

Objek yang menjadi bahan penelitian ini adalah perbedaan karakteristik petani dan usahatani mangga di Kecamatan Panyingkiran, Kabupaten Majalengka dan Kecamatan Japara, Kabupaten Kuningan, Jawa Barat. Pemilihan lokasi penelitian dilakukan secara sengaja dengan mempertimbangkan bahwa Kecamatan Panyingkiran dan Kecamatan Japara merupakan salah satu kecamatan di daerah sentra produksi mangga Jawa Barat yang memiliki potensi untuk dikembangkan.

Desain penelitian yang digunakan dalam penelitian ini menggunakan penelitian kuantitatif. Metode penelitian yang digunakan dalam penelitian ini metode analisis data sekunder dengan hasil survey. 


\section{Sumber Data dan Teknik Pengumpulan Data}

Pada penelitian ini, data yang digunakan dalam penelitian adalah data sekunder. Teknik pengumpulan data sekunder ini diperoleh dari studi literatur yang sudah ada, penelitian terdahulu, jurnal penelitian maupun dokumentasi yang terkait dengan penelitian ini.

Populasi adalah seluruh kumpulan data dalam ruang lingkup dan waktu yang sudah ditentukan oleh peneliti. Ukuran atau banyaknya populasi akan sama banyaknya manusia (Margono, 2004). Jumlah populasi petani mangga di Kecamatan Panyingkiran adalah 919 orang petani mangga atau $\mathrm{N}=919$. Lalu untuk jumlah populasi petani mangga di Kecamatan Japara berjumlah 901 orang petani mangga atau $\mathrm{N}=901$.

Sampel merupakan bagian dari jumlah dan karakteristik yang ada dari populasi penelitian tersebut (Sugiyono, 2017). Teknik pengambilan sampel pada penelitian ini menggunakan simple random sampling. Dalam perhitungan sampel penelitian ini menggunakan rumus slovin, sehingga perhitungan jumlah sampel di Kecamatan Panyingkiran sejumlah 91 orang dan 89 orang untuk Kecamatan Japara. Untuk menghindari kesalahan pada saat pengambilan data, sebaiknya peneliti mengambil sampel melebihi standar perhitungan yaitu sebesar 130 orang petani di Kecamatan Panyingkiran dan 130 orang petani di Kecamatan Japara.

Analisis data yang digunakan oleh peneliti bertujuan untuk menjelaskan suatu data agar lebih mudah dipahami sehingga dapat dibuat menjadi suatu kesimpulan yang mampu menjawab terhadap pertanyaan penelitian. Metode yang digunakan untuk menjawab pertanyaan penelitian ini adalah:

Analisis statistika deskriptif adalah alat analisis data yang digunakan dalam menganalisis data dengan cara mendeskripsikan atau menjelaskan data yang sudah terkumpul agar ditarik suatu kesimpulan yang berlaku umum atau generalisasi. Analisis statistika deskriptif pada penelitian ini digunakan untuk mendeskripsikan karakteristik petani dan usahatani mangga di Kecamatan Panyingkiran dan Kecamatan Japara. Data akan disajikan dalam bentuk distribusi frekuensi dan diagram bar.

\section{Uji Independent Sample T-Test}

Menurut Santoso independent sample $t$ test (uji $\mathrm{t}$ dua sampel bebas) digunakan untuk melihat dan mengetahui perbedaan atau perbandingan rata-rata dari dua grup yang tidak saling berhubungan. Data yang 
digunakan dalam uji independent sample t-test ini berupa data berdistribusi normal dengan skala interval atau rasio. Independent sample t-test memiliki Hipotesis sebagai berikut:

- $\mathrm{H}_{0}$ : Tidak terdapat perbedaan yang signifikan terhadap suatu variabel diantara sampel 1 dan sampel 2.

- $\mathrm{H}_{1}$ : Terdapat perbedaan yang signifikan terhadap suatu variabel diantara sampel 1 dan sampel 2.

\section{Uji Mann Whitney U-Test}

Menurut Rasmikayati dkk (2020), Mann-Whitney U-Test adalah uji non parametrik yang digunakan untuk mengetahui perbedaan median 2 kelompok bebas apabila skala data variabel terikatnya adalah ordinal atau interval/ratio tetapi tidak berdistribusi normal. Dalam penelitian ini, MannWhitney U-Test digunakan untuk mengetahui perbedaan karakteristik petani dan usahatani mangga di Kecamatan Panyingkiran dan Kecamatan Japara untuk data yang bersifat ordinal dan interval atau rasio, tetapi tidak berdistribusi normal.

Hipotesis sebagai berikut:

- $\mathrm{H}_{0}$ : Tidak terdapat perbedaan yang signifikan terhadap suatu variabel diantara sampel 1 dan sampel 2.
- $\mathrm{H}_{1}$ : Terdapat perbedaan yang signifikan terhadap suatu variabel diantara sampel 1 dan sampel 2.

\section{HASIL DAN PEMBAHASAN}

\section{Gambaran Umum Lokasi Penelitian}

\section{Kecamatan Panyingkiran}

Kecamatan Panyingkiran sebagai salah satu sentra produksi mangga yang terletak di Kabupaten Majalengka meliputi 9 desa yang terdiri atas Desa Panyingkiran, Karyamukti, Jatipamor, Bantrangsana, Pasirmuncang, Cijurey, Jatiserang, Bonang, Leuwiseeng. Berdasarkan keadaan topografinya, Kecamatan Panyingkiran termasuk zona daerah dataran rendah dengan ketinggian $50 \mathrm{~m}$ di atas permukaan laut dan luas wilayah yang dimiliki adalah $\pm 21,84$ $\mathrm{km} 2$ yang merupakan sekitar $\pm 1,91 \%$ dari seluruh luas wilayah Kabupaten Majalengka yang memiliki luas sekitar \pm $1.204,24 \mathrm{~km} 2$.

Berdasarkan demografis, jumlah penduduk di Kecamatan Panyingkiran mencapai 31.876 jiwa dengan sex ratio 98. Hal ini menunjukkan bahwa setiap 100 orang penduduk laki-laki terdapat 102 orang penduduk perempuan.

\section{Kecamatan Japara}

Kecamatan Japara sabagai salah satu sentra produksi mangga yang 
terletak di Kabupaten Kuningan meliputi 10 desa yang terdiri atas Desa Garatengah, Japara, Singkup, Rajadanu, Dukuh Dalem, Wano, Citapen, Cengal, Cikeleng, Kalimati. Berdasarkan keadaan topografinya, Kecamatan Japara memiliki ketinggian bervariasi yaitu antara 425 sampai dengan $758 \mathrm{~m}$ di atas permukaan laut. Sebagian besar wilayah Kecamatan Japara merupakan dataran yang hampir merata, hanya beberapa desa yang ada di tempat yang lebih rendah. Sehingga ratarata ketinggian dari permukaan laut wilayah Kecamatan Japara berada pada $465 \mathrm{~m}$ di atas permukaan laut. Luas wilayah Kecamatan Japara 2.347,3 km2 yang merupakan 9,21\% dari seluruh luas wilayah Kabupaten Kuningan yang memiliki luas $25.478 \mathrm{~km} 2$

Berdasarkan demografis, jumlah penduduk di Kecamatan Japara mencapai 20.228 jiwa dengan sex ratio 104 . Hal ini menunjukkan bahwa setiap 100 orang penduduk perempuan terdapat 104 orang penduduk laki-laki.

\section{Karakteristik Petani dan Usahatani Mangga di Kecamatan Panyingkiran dan Kecamatan Japara}

\section{Usia}

Mardikanto dalam Sitanggang (2016) menyatakan bahwa usia berkaitan erat dengan kegiatan berusahatani terutama dalam mengadopsi suatu teknologi baru.

Tabel 3. Usia Responden Petani Mangga

\begin{tabular}{ccccc}
\hline \multirow{2}{*}{$\begin{array}{c}\text { Usia } \\
\text { Tahun) }\end{array}$} & \multicolumn{2}{c}{$\begin{array}{c}\text { Kecamatan } \\
\text { Panyinkiran }\end{array}$} & \multicolumn{2}{c}{$\begin{array}{c}\text { Kecamatan } \\
\text { Japara }\end{array}$} \\
\cline { 2 - 5 } & $\mathrm{n}$ & $\%$ & $\mathrm{n}$ & $\%$ \\
\hline$<30$ & 6 & 5 & 2 & 2 \\
$31-40$ & 23 & 18 & 8 & 6 \\
$41-50$ & 41 & 31 & 37 & 28 \\
$51-60$ & 33 & 25 & 34 & 26 \\
$>61$ & 27 & 21 & 49 & 38 \\
\hline Total & 130 & 100 & 130 & 100 \\
\hline Rata-rata & \multicolumn{2}{c}{51 Tahun } & 57 Tahun \\
\hline \multicolumn{3}{c}{ Nilai Sig. (2-tailed) $0,00 * * *<0,05$} \\
\hline Ket: Nilai Sig. (2-tiled) $<0,05$ Tolak
\end{tabular}

Ket: Nilai Sig. (2-tailed) $<0,05$ Tolak $\mathrm{H}_{0}$ Nilai Sig. (2-tailed) $>0,05$ Terima $\mathrm{H}_{0}$

Berdasarkan Tabel 7, diketahui bahwa mayoritas petani mangga di Kecamatan Panyingkiran yaitu $41 \%$ dari total petani responden merupakan petani berusia 41-50 tahun. Petani mangga termuda di Kecamatan Panyingkiran yakni berusia 23 tahun, sedangkan untuk petani dengan usia paling tua adalah 87 tahun, dan rata-rata usia petani mangga di Kecamatan Panyingkiran adalah 51 tahun. Adapun petani mangga di Kecamatan Japara yaitu 49\% dari total responden merupakan petani berumur $>61$ tahun. Petani mangga termuda di Kecamatan Japara yakni berumur 27 tahun, sedangkan petani dengan usia paling tua adalah 87 tahun, dan rata-rata usia petani mangga di Kecamatan Japara adalah 57 tahun. Selain itu, diketahui bahwa nilai sig. (2-tailed) $0,00<0,05$ artinya tolak $\mathrm{H} 0$ atau terdapat perbedaan 
yang signifikan antara usia petani mangga di Kecamatan Panyingkiran dan Kecamatan Japara. Menurut Departemen Kesehatan Republik Indonesia (2009) menjelaskan bahwa umur manusia dibagi menjadi rentang beberapa kelompok yaitu sebagai berikut, masa balita dan kanak-kanak 0-12 tahun, masa remaja 1225 tahun, masa dewasa 26-45 tahun, masa lansia 46-64 tahun, masa manula $>65$ tahun. Sedangkan menurut Prijono (2001) usia produktif manusia berada di usia 15-64 tahun.

Penelitian ini menunjukkan bahwa rata-rata usia petani di Kecamatan Panyingkiran dan Kecamatan Japara merupakan usia yang produktif dalam bekerja. Akan tetapi sangat disayangkan hanya terdapat sedikit sekali petani yang berusia di bawah 25 tahun padahal usia tersebut merupakan usia dimana seseorang memiliki kekuatan bekerja yang baik, dan apabila semakin tua usia petani akan semakin lamban dalam mengadopsi sebuah teknologi atau inovasi baru. Menurut Elfadina (2018), anak-anak muda lebih memilih untuk bekerja di perkantoran dan di perkotaan dibandingkan di sektor pertanian terutama di usahatani mangga.

\section{Jenis Kelamin}

Menurut Hungu (2007), jenis kelamin adalah perbedaan antara perempuan dengan laki-laki secara biologis sejak seseorang lahir serta memiliki orientasi sikap dan perilaku yang berbeda.

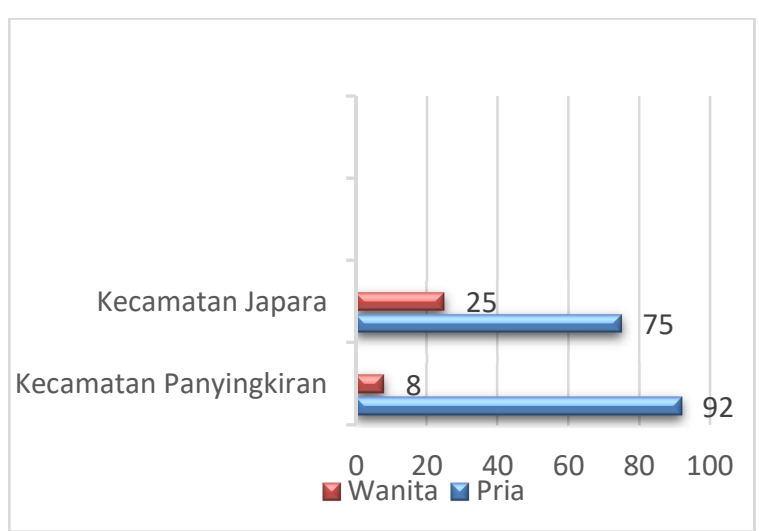

Gambar 1. Jenis Kelamin Responden Petani Mangga

Berdasarkan Gambar 1, diketahui bahwa mayoritas responden petani mangga di Kecamatan Panyingkiran adalah berjenis kelamin pria dengan $92 \%$ dan petani wanita menjadi minoritas dengan $8 \%$. Sedangkan mayoritas untuk responden petani mangga di Kecamatan Japara adalah berjenis kelamin pria dengan $75 \%$ dan petani wanita menjadi minoritas dengan $25 \%$. Petani pria yang mengusahakan tanaman mangga lebih banyak dibandingkan petani wanita disebabkan pekerjaan ini terbilang cukup berat dan juga petani pria merupakan kepala keluarga yang bertanggung jawab kepada keluarganya. 
Berdasarkan perhitungan Mann Whitney-U untuk variabel jenis kelamin diketahui bahwa nilai Sig. (2-tailed) 0,00 $<0,05$ artinya tolak $\mathrm{H} 0$ atau terdapat perbedaan yang signifikan antara jenis kelamin petani mangga di Kecamatan Panyingkiran dan Kecamatan Japara.

Ramadhani dkk (2017) menyatakan bahwa petani mangga wanita yang mengusahakan tanaman mangga di Kecamatan Panyingkiran karena wanita tersebut merupakan seorang janda yang diwariskan kebun mangga oleh suaminya dahulu, atau ikut membantu suami bertani mangga.

\section{Tingkat Pendidikan}

Menurut Suhardjo (2007), tingkat pendidikan adalah tahapan pendidikan yang telah ditempuh petani dengan tujuan yang akan dicapai dan kemauan yang akan dikembangkan.

Berdasarkan Tabel 4, diketahui bahwa 55\% dari responden petani mangga di Kecamatan Panyingkiran memiliki pendidikan terakhir Sekolah Dasar (SD). Sedangkan 70\% responden petani mangga di Kecamatan Japara memiliki pendidikan akhir SD.

Berdasarkan perhitungan MannWhitney U-Test diketahui nilai Sig. (2tailed) $0,00 * * *<0,05$ artinya keputusan Ho ditolak atau terdapat perbedaan yang signifikan antara tingkat pendidikan petani mangga di Kecamatan Panyingkiran dan Kecamatan Japara.

Tabel 4. Tingkat Pendidikan Petani Mangga

\begin{tabular}{|c|c|c|c|c|}
\hline \multirow{2}{*}{$\begin{array}{c}\text { Tingkat } \\
\text { Pendidikan }\end{array}$} & \multicolumn{2}{|c|}{$\begin{array}{l}\text { Kecamatan } \\
\text { Panyinkiran }\end{array}$} & \multicolumn{2}{|c|}{$\begin{array}{c}\text { Kecamatan } \\
\text { Japara }\end{array}$} \\
\hline & $\mathrm{n}$ & $\%$ & $\mathrm{n}$ & $\%$ \\
\hline $\begin{array}{l}\text { Tidak } \\
\text { Sekolah }\end{array}$ & 5 & 4 & 25 & 19 \\
\hline SD & 72 & 55 & 90 & 69 \\
\hline SMP & 20 & 15 & 7 & 5 \\
\hline SMA & 27 & 21 & 5 & 4 \\
\hline $\begin{array}{l}\text { Akademisi } \\
\text { / Diploma }\end{array}$ & 2 & 2 & 2 & 2 \\
\hline Sarjana & 4 & 3 & 1 & 1 \\
\hline Total & 130 & 100 & 130 & 100 \\
\hline
\end{tabular}

Ket: Nilai Sig. (2-tailed) $<0,05$ Tolak $\mathrm{H}_{0}$ Nilai Sig. (2-tailed) $>0,05$ Terima $\mathrm{H}_{0}$

Hal ini menunjukkan bahwa pendidikan petani di Kecamatan Panyingkiran dan Kecamatan Japara masih rendah. Pendidikan petani yang rendah disebabkan bahwa dahulu pendidikan masih menjadi sesuatu yang mahal dan orang tua petani tersebut tidak mampu untuk menyekolahkannya. Dalam hal budidaya tanaman mangga, petani melakukan kegiatan tersebut secara otodidak dan hanya diskusi dengan rekan-rekan petani mangga yang sudah berhasil dalam usahatani mangga.

\section{Pekerjaan Utama dan Pekerjaan sampingan Petani Mangga}

Taliziduhu Ndraha menyatakan bahwa pekerjaan merupakan proses penciptaan sumberdaya untuk memenuhi kebutuhan yang ada. Pekerjaan pada penelitian ini dibagi 2, 
yaitu pekerjaan utama dan pekerjaan sampingan. Pekerjaan utama merupakan pekerjaan yang dijadikan fokus pertama dalam melakukan sesuatu. Sedangkan pekerjaan sampingan merupakan pekerjaan yang dapat dilakukan apabila kegiatan lain telah selesai dilakukan.

Tabel 5. Pekerjaan Utama dan Sampingan Petani Mangga

\begin{tabular}{|c|c|c|c|c|}
\hline \multirow[t]{2}{*}{ Pekerjaan } & \multicolumn{2}{|c|}{$\begin{array}{c}\text { Kecamatan } \\
\text { Panyinkiran }\end{array}$} & \multicolumn{2}{|c|}{$\begin{array}{c}\text { Kecamatan } \\
\text { Japara }\end{array}$} \\
\hline & $\mathrm{n}$ & $\%$ & $\mathrm{n}$ & $\%$ \\
\hline \multicolumn{5}{|c|}{ Utama } \\
\hline PNS & 4 & 3 & 1 & 1 \\
\hline $\begin{array}{l}\text { Petani } \\
\text { Mangga }\end{array}$ & 115 & 88 & 6 & 5 \\
\hline Pedagang & 6 & 5 & 6 & 5 \\
\hline Lainnya & 5 & 4 & 117 & 89 \\
\hline Total & 130 & 100 & 130 & 100 \\
\hline \multicolumn{5}{|c|}{ Nilai Sig. (2-tailed) $0,00 * * *<0,05$} \\
\hline \multicolumn{5}{|c|}{ Sampingan } \\
\hline Tidak ada & 37 & 59 & 1 & 31 \\
\hline PNS & 2 & 1 & 0 & 0 \\
\hline $\begin{array}{l}\text { Petani } \\
\text { Mangga }\end{array}$ & 19 & 15 & 124 & 95 \\
\hline Pedagang & 16 & 10 & 1 & 1 \\
\hline Lainnya & 56 & 45 & 4 & 3 \\
\hline Total & 130 & 100 & 130 & 100 \\
\hline
\end{tabular}

Ket: Nilai Sig. (2-tailed) $<0,05$ Tolak $\mathrm{H}_{0}$ Nilai Sig. (2-tailed) $>0,05$ Terima $\mathrm{H}_{0}$

Berdasarkan Tabel 5, diketahui sebagian besar atau $88 \%$ responden petani mangga di Kecamatan Panyingkiran menjadikan usahatani mangga sebagai pekerjaan utamanya. Selain itu, hanya $15 \%$ yang menjadikan usahatani mangga sebagai pekerjaan sampingan; dan terdapat $28 \%$ responden petani yang tidak memiliki pekerjaan sampingan dan menjadikan usahatani mangga sebagai satu-satunya pekerjaan mereka. Berbeda dengan 96\% responden petani mangga di Kecamatan Japara yang menjadikan usahatani mangga sebagai pekerjaan sampingan dan hanya 5\% responden petani yang menjadikan usahatani mangga sebagai pekerjaan utamanya, serta hanya 1\% yang tidak memiliki pekerjaan sampingan dan menjadikan usahatani mangga sebagai satu-satunya pekerjaan mereka.

Berdasarkan hasil perhitungan Mann Whitney U diketahui terdapat nilai Sig. (2-tailed) $0,00 * * *<0,05$ yang artinya tolak $\mathrm{H} 0$ atau terdapat perbedaan yang signifikan antara pekerjaan utama atau pekerjaan sampingan petani mangga di Kecamatan Panyingkiran dan Japara.

Mayoritas petani mangga di Kecamatan Panyingkiran memiliki pekerjaan sampingan yang cukup beragam dimulai dari buruh, pedagang, petani padi, petani swadaya, penjahit, bandar/tengkulak, petani palawija dan lain sebagainya. Sedangkan mayoritas petani mangga di Kecamatan Japara memiliki pekerjaan utama seperti buruh tani, pensiunan pns, petani padi, ibu rumah tangga, peternak dan lain sebagainya.

\section{Pengalaman Usahatani Petani Mangga \\ Pengalaman menurut Daehler \&} Bukatko (1985) yaitu memori yang 
menerima dan menyimpan peristiwa yang terjadi atau dialami individu pada waktu dan tempat tertentu.

Tabel 6. Pengalaman Usahatani Petani Mangga

\begin{tabular}{ccccc}
\hline $\begin{array}{c}\text { Pengalaman } \\
\text { Usahatani } \\
\text { (Tahun) }\end{array}$ & \multicolumn{2}{c}{$\begin{array}{c}\text { Kecamatan } \\
\text { Panyinkiran }\end{array}$} & \multicolumn{2}{c}{$\begin{array}{c}\text { Kecamatan } \\
\text { Japara }\end{array}$} \\
\cline { 2 - 5 }$<10$ & $\mathrm{n}$ & $\%$ & $\mathrm{n}$ & $\%$ \\
\hline $10-20$ & 31 & 39 & 67 & 51 \\
$>20$ & 40 & 31 & 22 & 17 \\
\hline Total & 130 & 100 & 130 & 100 \\
\hline Rata-rata & \multicolumn{2}{c}{18,2 Tahun } & \multicolumn{2}{c}{14,8 Tahun } \\
\hline
\end{tabular}
Nilai Sig. (2-tailed) $0,047 * *<0,05$

Ket: Nilai Sig. (2-tailed) $<0,05$ Tolak $\mathrm{H}_{0}$ Nilai Sig. (2-tailed) $>0,05$ Terima $\mathrm{H}_{0}$

Mayamsari dan Mujiburrahmad (2014) mengelompokkan pengalaman usahatani ke dalam 3 kelompok, yaitu:

1. Pengalaman usahatani baru/kurang berpengalaman untuk di bawah 10 tahun.

2. Pengalaman usahatani cukup berpengalaman diantara 10-20 tahun.

3. Pengalaman usahatani lama atau sangat berpengalaman untuk di atas 20 tahun.

Berdasarkan Tabel 6, menunjukkan bahwa 39\% responden petani mangga di Kecamatan Panyingkiran memiliki pengalaman di bawah 10 tahun atau terbilang masih baru dalam melakukan usahatani mangga. Selain itu, terdapat $30 \%$ petani mangga yang memiliki pengalaman yang cukup dan $31 \%$ petani yang sangat berpengalaman atau lebih dari 20 tahun mengusahakan tanaman mangga. Rata-rata reponden petani mangga di Kecamatan Panyingkiran berpengalaman cukup atau selama 18,2 tahun. Sedangkan 51\% responden petani mangga di Kecamatan Japara memiliki pengalaman di bawah 10 tahun atau terbilang masih kurang berpengalaman. Selain itu, terdapat $32 \%$ petani mangga yang berpengalaman cukup dan 17\% petani yang sangat berpengalaman atau lebih dari 20 tahun. Rata-rata responden petani mangga di Kecamatan Japara berpengalaman cukup atau selama 14,8 tahun.

Berdasarkan perhitungan dari alat analisis Mann Whitney $U$ diperoleh nilai Sig. (2-tailed) 0,047** >0,05 maka memiliki arti yaitu terima $\mathrm{H} 0$ atau tidak terdapat perbedaan yang signifikan antara pengalaman usahatani petani mangga di Kecamatan Panyingkiran dan Kecamatan Japara.

Widyarina (2018) menyatakan bahwa pengalaman usahatani mangga di Kecamatan Panyingkiran yang belum terlalu lama yaitu sekitar 1/3 dari jumlah responden petani mangga. hal tersebut dikarenakan buah mangga belum menjadi komoditas utama yang mereka usahakan, petani lebih memilih menanam padi atau palawija. Dimulai tahun 2000 petani di Kecamatan Panyingkiran baru memulai 
menanam tanaman mangga dan banyak petani yang beralih dari menanam tanaman padi menjadi tanaman mangga. Sedangkan menurut Kusumo dkk (2019), kebanyakan petani mangga di Kabupaten Kuningan mengusahakan mangga secara turun temurun dari orang tua dan sebagian besar petani memiliki pengalaman berusahatani mangga di bawah 20 tahun.

\section{Pendapatan dari Bertani Mangga dan Selain Bertani Mangga}

Menurut Munandar (1981), pendapatan adalah suatu penambahan aset yang mengakibatkan bertambahnya kekayaan untuk petani sendiri dan bukan karena penambahan modal dari petani serta bukan juga karena penambahan asset

Berdasarkan Tabel 7, diketahui bahwa mayoritas responden petani mangga di Kecamatan Panyingkiran sebesar $44 \%$ dan $49 \%$ responden petani mangga di Kecamatan Japara memiliki pendapatan Rp10.000.001-Rp 50.000.000 dari bertani mangga. Adapun pendapatan terendah petani mangga di Kecamatan Panyingkiran sebesar Rp1.500.000 sedangkan pendapatan terendah petani mangga di Kecamatan Japara sebesar Rp150.000 dari bertani mangga. Selain itu, terdapat pendapatan tertinggi petani mangga di Kecamatan Panyingkiran sebesar Rp1.500.000.000, sedangkan pendapatan tertinggi petani mangga di Kecamatan Japara sebesar Rp200.000.000 dari bertani mangga. Rata-rata pendapatan petani dari bertani mangga di Kecamatan Panyingkira sebesar Rp104.235.577 dan Rp6.424.230 untuk petani mangga di Kecamatan Japara.

Mayoritas responden petani mangga di Kecamatan Panyingkiran sebesar $37 \%$ dan $64 \%$ responden petani mangga di Kecamatan Japara juga memiliki pendapatan yang berasal bukan bertani mangga dibawah Rp10.000.000. Pendapatan terendah petani mangga yang berasal bukan dari bertani mangga di Kecamatan Panyingkiran sebesar Rp2.000.000 dan pendapatan terendah petani mangga di Kecamatan Japara sebesar Rp500.000. Adapun pendapatan tertinggi petani mangga yang berasal dari bukan bertani mangga di Kecamatan Panyingkiran adalah Rp200.000.000 dan pendapatan tertinggi petani mangga yang berasal dari bukan bertani mangga di Kecamatan Japara sebesar Rp100.000.000. Rata-rata pendapatan petani mangga yang berasal dari bukan bertani mangga di Kecamatan Panyingkiran sebesar Rp19.357.941 dan rata-rata pendapatan petani mangga yang 
berasal dari bukan bertani mangga di Kecamatan Japara sebesar Rp7.418.846. Selain itu, terdapat $35 \%$ petani mangga di Kecamatan Panyingkiran dan 20\% petani mangga di Kecamatan Japara yang tidak menjawab terkait pendapatan yang berasal bukan bertani mangga.

Berdasarkan perhitungan alat analisis Mann Whitney $U$ terdapat hasil nilai Sig. (2-tailed) $0,00^{* * *}<0,05$ artinya tolak $\mathrm{H} 0$ atau terdapat perbedaan yang signifikan pendapatan bertani mangga dan pendapatan selain bertani mangga di Kecamatan Panyingkiran dan Kecamatan Japara. Hal ini terlihat bahwa rata-rata pendapatan petani mangga yang berasal dari bertani mangga maupun pendapatan non bertani mangga diantara Kecamatan Panyingkiran dan Kecamatan Japara memiliki perbedaan yang signifikan.

\section{Menurut Rasmikayati} mengenai pendapatan usahatani mangga dengan mengkategorikan tingkat pendapatan petani mangga. Petani yang memiliki pendapatan kurang dari Rp11 juta per-musim dikategorikan sebagai petani dengan pendapatan rendah, sedangkan petani dengan pendapatan antara Rp11 juta hingga Rp32 Juta permusim dikategorikan sebagai petani dengan pendapatan sedang, dan untuk petani dengan pendapatan lebih dari Rp32 juta per-musim termasuk ke dalam kategori petani dengan pendapatan tinggi.

Tabel 7. Pendapatan dari Bertani Mangga dan Selain Bertani Mangga

\begin{tabular}{|c|c|c|c|c|}
\hline \multirow{2}{*}{$\begin{array}{c}\text { Pendapatan } \\
\text { (Rp) }\end{array}$} & \multicolumn{2}{|c|}{$\begin{array}{l}\text { Kecamatan } \\
\text { Panyinkiran }\end{array}$} & \multicolumn{2}{|c|}{$\begin{array}{c}\text { Kecamatan } \\
\text { Japara }\end{array}$} \\
\hline & $\mathrm{n}$ & $\%$ & $\mathrm{n}$ & $\%$ \\
\hline \multicolumn{5}{|c|}{ Pendapatan dari bertani mangga } \\
\hline$<10.000 .000$ & 26 & 20 & 35 & 27 \\
\hline $\begin{array}{l}10.000 .001- \\
50.000 .000\end{array}$ & 57 & 44 & 63 & 49 \\
\hline $\begin{array}{l}50.000 .001- \\
100.000 .000\end{array}$ & 25 & 19 & 20 & 15 \\
\hline$>100.000 .000$ & 22 & 17 & 12 & 9 \\
\hline Total & 130 & 100 & 130 & 100 \\
\hline Rata-rata & \multicolumn{2}{|c|}{ Rp 104.235.577 } & \multicolumn{2}{|c|}{$\mathrm{Rp} 6.424 .230$} \\
\hline \multicolumn{5}{|c|}{ Nilai Sig. (2-tailed) $0,00 * * *<0,05$} \\
\hline \multicolumn{5}{|c|}{ Pendapatan Pertahun dari Selain Bertani Mangga } \\
\hline Tidak ada & 45 & 68 & 26 & 50 \\
\hline$<10.000 .000$ & 51 & 37 & 83 & 64 \\
\hline $\begin{array}{l}10.000 .001- \\
50.000 .000\end{array}$ & 29 & 22 & 19 & 15 \\
\hline $\begin{array}{l}50.000 .001- \\
100.000 .000\end{array}$ & 3 & 2 & 2 & 1 \\
\hline$>100.000 .001$ & 2 & 1 & 0 & 0 \\
\hline Total & 130 & 100 & 130 & 100 \\
\hline Rata-rata & \multicolumn{2}{|c|}{ Rp 19.357.941 } & \multicolumn{2}{|c|}{$\mathrm{Rp} 7.418 .846$} \\
\hline \multicolumn{5}{|c|}{ Nilai Sig. (2-tailed) $0,00 * * *<0,05$} \\
\hline $\begin{array}{l}\text { Nilai Sig. } \\
\text { Nilai Sig. }\end{array}$ & . $(2-\mathrm{ta}$ & $\begin{array}{l}<0,05 \\
>0,05\end{array}$ & Oian & \\
\hline
\end{tabular}

\section{Penguasaan Lahan Petani Mangga}

Menurut Utomo (1992), lahan memiliki fungsi dasar, yakni: (1) fungsi kegiatan budaya, yakni lahan merupakan suatu kawasan yang dapat dimanfaatkan untuk berbagai penggunaan, seperti pemukiman, baik sebagai kawasan perkotaan maupun pedesaan, perkebunan, hutan produksi, dan lain lain. Penguasaan lahan dapat diartikan sebagai pemeliharaan atau kepemilikan suatu lahan mengenai status hukum dari 
penguasaan tanah seperti hak milik, gadai, bagi hasil, sewa-menyewa, dan juga kedudukan buruh tani. Penguasaan lahan dalam penelitian ini antara lain total luas lahan dan jumlah pohon mangga.

Tabel 8. Luas Lahan dan Jumlah Pohon Mangga

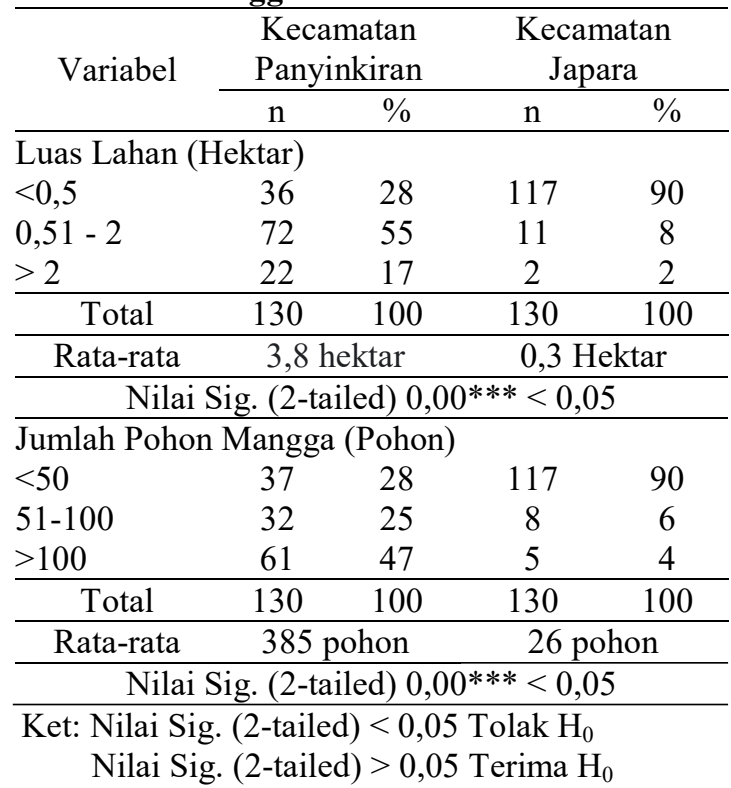

Berdasarkan Tabel 8, diketahui bahwa mayoritas responden petani mangga di Kecamatan Panyingkiran sebesar 55\% memiliki total luas lahan 0,51 - 2 Hektar, sedangkan mayoritas responden petani mangga di Kecamatan Japara sebesar 90\% memiliki luas lahan di bawah 0,5 hektar. Adapun total luas lahan kebun mangga yang paling luas di Kecamatan Panyingkiran sebesar 302 hektar dan 3 hektar untuk Kecamatan Japara. Selain itu, terdapat rata-rata luas lahan kebun mangga di Kecamatan
Panyingkiran sebesar 3,8 hektar dan 0,3 hektar untuk Kecamatan Japara. Menurut Elfadina dkk. (2019), dalam mengkategorikan pengusaan lahan petani mangga menjadi 3 kategori, petani dengan lahan $\leq 0,5$ Ha termasuk ke dalam kategori petani berlahan sempit, sedangkan petani dengan luas lahan 0,51 - 2 Ha merupakan petani berlahan sedang, dan petani dengan luas lahan $>2$ Ha merupakan petani berlahan luas.

Berdasarkan Tabel 8 juga menunjukkan mayoritas responden petani mangga di Kecamatan Panyingkiran memiliki jumlah pohon di atas 100 pohon, sedangkan mayoritas petani mangga di Kecamatan Japara memiliki jumlah pohon di bawah 50 pohon. Terdapat juga jumlah pohon terbanyak di Kecamatan Panyingkiran sebesar 22.200 pohon dan 200 pohon di Kecamatan Japara. Rata-rata jumlah pohon di Kecamatan Panyingkiran sebanyak 385 pohon dan 26 pohon di Kecamatan Japara. Dalam penelitian ini petani dengan kepemilikan pohon mangga lebih dari 100 pohon termasuk ke dalam kategori petani mangga skala besar, sedangkan untuk petani yang mempunyai pohon mangga antara 50 hingga 100 pohon termasuk ke dalam kategori petani mangga skala sedang, dan untuk petani 
mangga dengan pohon mangga kurang dari 50 pohom termasuk ke dalam petani mangga skala kecil.

Berdasarkan perhitungan alat analisis data Mann Whitney $U$ terdapat nilai Sig. (2-tailed) $0,00 * * *<0,05$ yang artinya tolak $\mathrm{H} 0$ atau terdapat perbedaan luas lahan dan jumlah pohon petani mangga di Kecamatan Panyingkiran dan Kecamatan Japara. Dalam hal ini penguasaan lahan diantara petani mangga di Kecamatan Panyingkiran dan Kecamatan Japara memiliki perbedaan dimana rata-rata luas lahan dan total pohon mangga yang dimiliki petani mangga di Kecamatan Panyingkiran lebih luas dan banyak dibandingkan petani mangga di Kecamatan Japara. Salah satu penyebabnya adalah mayoritas responden petani mangga di Kecamatan Japara masih menjadikan usahatani mangga sebagai pekerjaan sampingan dan memiliki pekerjaan utama lainnya sehingga tidak terlalu fokus untuk mengembangkannya, padahal sangat disayangkan jika dapat terus dikembangkan usahatani mangga merupakan usaha yang dapat menjanjikan jika melihat pendapatan per tahunnya.

\section{KESIMPULAN DAN SARAN}

Kecamatan Panyingkiran dan Kecamatan Japara merupakan daerah sentra produksi mangga di Jawa Barat.

Karakteristik petani dan usahatani mangga diantara Kecamatan Panyingkiran dan Kecamatan Japara memiliki perbedaan yang signifikan terhadap usia petani, jenis kelamin petani, tingkat pendidikan petani, pekerjaan utama ataupun pekerjaan sampingan petani, pengalaman usahatani petani mangga, pendapatan petani dari bertani maupun selain bertani mangga dan penguasaan lahan petani mangga yang terdiri atas total luas lahan dan jumlah pohon mangga.

Dalam melakukan budidaya tanaman mangga alangkah lebih baik apabila petani dapat mengikuti kegiatan pelatihan mangga sehingga dapat lebih memiliki pengalaman dan diharapkan dapat mengembangkan usahatani mangga tersebut.

\section{DAFTAR PUSTAKA}

[BPS dan DJH]. Badan Pusat Statistik dan Direktorat Jendral Hortikultura. 2018. Luas Panen, Produksi dan Produktivitas Mangga Tahun 20172018.

[BPS]. Badan Pusat Statistik. (2019). Statistik Hortikultura.

Azizah, M. N., Rasmikayati, E., \& Saefudin, B. R. (2019). Perilaku 
budidaya petani mangga dikaitkan dengan lembaga pemasarannya di Kecamatan Greged Kabupaten Cirebon. Jurnal Ilmiah Mahasiswa Agroinfo Galuh, 5(1), 987-998.

Badan Pusat Statistik 2018. Katalog BPS: Luas Panen, Produksi dan Produktivitas Mangga Tahun 20172018 Berdasarkan Provinsi Unggulan.

Badan Pusat Statistik Jawa Barat 20152019. Katalog BPS: Total produksi buah mangga di Jawa Barat 20152019.

Elfadina, E. A. (2018). Pengembangan Agribisnis Mangga Ditinjau dari Penguasaan Lahan dan Kebijakan Pemerintah Terkait (Doctoral dissertation).

Elfadina, E. A., Rasmikayati, E., \& Saefudin, B. R. (2019). Analisis luas dan status penguasaan lahan petani mangga dikaitkan dengan perilaku agribisnisnya di Kecamatan Cikedung Kabupaten Indramayu. Jurnal Ilmiah Mahasiswa Agroinfo Galuh, 6(1), 69-79.

Kusumo, R. A. B., Rasmikayati, E., Mukti, G. W., Fatimah, S., \& Saefudin, B. R. (2018). FaktorFaktor yang mempengaruhi keputusan petani mangga dalam menggunakan teknologi off season di Kabupaten Cirebon. Mimbar Agribisnis: Jurnal Pemikiran Masyarakat Ilmiah Berwawasan Agribisnis, 4(1), 57-69.

Manyamsari, I., \& Mujiburrahmad, M. (2014). Karakteristik Petani Dan Hubungannya Dengan Kompetensi Petani Lahan Sempit (Kasus: Di Desa Sinar Sari Kecamatan Dramaga Kab. Bogor Jawa Barat). Jurnal Agrisep, 15(2), 58-74.

Mukti, G. W., Rasmikayati, E., Kusumo, R. A. B., \& Fatimah, S. (2018). Perilaku Kewirausahaan Petani
Mangga dalam Sistem Agribisnis di Kabupaten Majalengka Provinsi Jawa Barat. Mimbar Agribisnis: Jurnal Pemikiran Masyarakat Ilmiah Berwawasan Agribisnis, 4(1), 40-56.

Nadapdap, H. J., \& Saefudin, B. R. (2020). Risiko Usahatani Mangga di Kecamatan Rembang Jawa Tengah. Jurnal Penelitian Pertanian Terapan, 20(2), 161-169. Rachmah, A. D., Rasmikayati, E., \& Saefudin, B. R. (2019). Factors related to continuation of mango cultivation. Jurnal Pertanian, 10(2), 52-60.

Ramadhani, W., \& Rasmikayati, E. (2018). Dinamika agribisnis petani mangga di Kecamatan Panyingkiran Kabupaten Majalengka Provinsi Jawa Barat. Jurnal Ilmiah Mahasiswa Agroinfo Galuh, 4(3), 873-880.

Rasmikayati, E. (2018). Kajian Potensi dan Kendala dalam Proses Usahatani dan Pemasaran Mangga di Kabupaten Indramayu. Sosiohumaniora, 20(3), 215-221.

Rasmikayati, E., \& Saefudin, B. R. (2018). Analisis Faktor-Faktor Yang Mampu Mendorong Petani Mangga Untuk Meningkatkan Perilaku Agribisnisnya Pada Era Globalisasi. Paradigma Agribisnis, 1(1), 1-13.

Rasmikayati, E., \& Saefudin, B. R. (2018). Confirmatory Factor Analysis: Faktor-Faktor Penentu Agribisnis Mangga Di Kabupaten Majalengka Berdasarkan Penguasaan Lahannya. Jurnal Agribisnis Terpadu, 11(1), 100109.

Rasmikayati, E., Elfadina, E. A., Kusumo, R. A. B., Saefudin, B. R., \& Supriyadi, S. (2020). Policy Analysis of Mango's Agribusiness Development (A Case in Cikedung 
District, Indramayu Regency). Jurnal Manajemen \& Agribisnis, 17(1), 52-52.

Rasmikayati, E., Kusumo, R. A. B., Mukti, G. W., \& Saefudin, B. R. (2020); Comparison of Willingness to Process Fresh Mango into Processed Mango Products between Mango Farmers In Majalengka and Kuningan Regency, West Java; International Journal of Scientific and Research Publications (IJSRP) 10(12) (ISSN: 2250-3153), DOI: http://dx.doi.org/10.29322/IJSRP.1 0.12.2020.p10847

Rasmikayati, E., Sulistyowati, L., \& Saefudin, B. R. (2017). Risiko Produksi dan Pemasaran Terhadap Pendapatan Petani Mangga: Kelompok Mana yang Paling Berisiko. Mimbar Agribisnis: Jurnal Pemikiran Masyarakat Ilmiah Berwawasan Agribisnis, 3(2), 105-116.
Santoso, S. (2014). Statistik parametrik edisi revisi. Jakarta: PT. Elex Media Komputindo.

Sari, A. F., Rasmikayati, E., \& Saefudin, B. R. (2019). Behavioral Dynamics of Farmers and First Buyer in Marketing Mangoes in Sedong District, Cirebon Regency, West Java. Agrifor, 18(1), 63-72.

Sugiyono, P. D. (2017). Metode Penelitian Bisnis: Pendekatan Kuantitatif, Kualitatif, Kombinasi, dan R\&D. Penerbit CV. Alfabeta: Bandung.

Suratiyah, K. (2006). Ilmu usahatani. Penebar Swadaya Grup. 